\title{
SOCIAL THOUGHT AND SOCIAL STATISTICS IN THE EARLY NINETEENTH CENTURY
}

\author{
THE CASE OF SANITARY STATISTICS IN ENGLAND*
}

The numerical determination of the relationship between the sanitary conditions in which people live, and the risks to health and life this may involve is a relatively new method of understanding infectious disease. It came to be known as "sanitary statistics" in the early nineteenth century, when this kind of investigation reached the climax of its social importance. But its roots go back to the late seventeenth century, when England was again visited by the plague, shattering a country that had hardly recovered from two decades of civil unrest. The two basic motives of sanitary statistics, which later made it so potent a reformist tool, were already present then in a first outline, namely the attempt to rationalize the frightful phenomenon of the epidemic and the conviction that its causes were somehow bound up with the social organization of urban life. As long as people had seen in the great epidemics God's punishing hand, the flagellants' reaction made sense. Man could only bow to Him; the arm of flesh might at most seek to avoid His punishment by punishing itself in advance. But when in 1854 the Presbytery of Edinburgh suggested to the Home Secretary, Lord Palmerston, to call for a national fast against cholera, they received the cold reply that "the weal or woe of mankind depends on the observance or neglect of those laws" which sanitary statistics had recently discovered. ${ }^{1}$ Divine reference was replaced by statistical reference, and the correlations thus revealed pointed to action by the "arm of flesh".

* An earlier version of this paper has been presented to the research group on "The Probabilistic Revolution: Dynamics of Scientific Development, 1800-1930", at the Centre for Interdisciplinary Research of the University of Bielefeld in March 1983. I should like to express my thanks to Professors William Coleman (Madison, Wisconsin), Ian Hacking (Toronto) and Lorenz Krüger (Berlin).

1 Cf. W. M. Frazer, A History of English Public Health, 1834-1934 (London, 1950), p. 4. 
This development began in the ideological upheaval of the English Revolution, when "Providence" lost its theological unity. ${ }^{2}$ The phenomena became facts belonging first and foremost to the world of man. They were now "perceptible to reason", as John Graunt, the founder of statistics, ${ }^{3}$ remarked when speaking of that overwhelming manifestation of Providence which death is to man. In employing the numerical method, one could discover regularities similar to those, it seemed, which the rising sciences endeavoured to ascertain. It was the London merchant John Graunt who, in his Natural and Political Observations [. . . ] upon the Bills of Mortality of 1662, made the first attempt to bring systematic questions to bear upon the data related to mortality.

Since 1348 the plague had hit Britain severely time and again. ${ }^{4}$ The densely populated areas, particularly London, suffered worst, while the "barbarous" Western and Northern regions often remained untouched. Registers of deaths and births had been kept in London since the sixteenth century in a first, frightened attempt to rationalize epidemic disease by observing its rise and decline numerically. From the devastating year of 1603 those lists had been published regularly. Deaths caused by the plague were singled out. These Bills of Mortality served as a kind of thermometer of urban health, and their publication was justified by declaring frankly that "in the Plague-time" they were to demonstrate "how the Sickness increased, or decreased, that so the Rich might judg of the necessity of their removal, and Trades-men might conjecture what doings they were like to have in their respective dealings". ${ }^{5}$ Reasoning from his parish registers, Graunt laid the foundations of statistics by formulating several numerical regularities. The most impressive result of his investigations was his law of mortality. ${ }^{6}$ In some sense connected with this law was the observation that not only certain diseases, but also "some Accidents, as Grief, Drowning, Men's making away themselves, and being Kill'd by several Accidents" "bear a constant proportion unto the whole number of Burials". ${ }^{7}$ The insight that "Providence" ruled suicide, too, was an astounding discovery which later

2 E. L. Tuveson, Millennium and Utopia, 2nd ed. (New York, 1964), pp. ix-x, 119, 132-225.

${ }^{3} \mathrm{H}$. Westergaard, Contributions to the History of Statistics (London, 1932), pp. 16-24.

${ }^{4} \mathrm{Ch}$. Creighton, A History of Epidemics in Britain (London, 1891), I, chs 3, 10, 12; F. F. Cartwright, A Social History of Medicine (London, 1977), ch. 4.

${ }^{5} \mathrm{~J}$. Graunt, "Natural and Political Observations Mentioned in a following Index, and made upon the Bills of Mortality", 5th ed. (1676), in: The Economic Writings of Sir William Petty, ed. by Ch. H. Hull (Cambridge, 1899), II, p. 333.

6 Ibid., p. 387.

7 Ibid., p. 352. 
gave rise to the second branch of social statistics, namely moral statistics. ${ }^{8}$ Although Graunt did not develop the possibility of an interrelationship between the statistics of death and those of morals, he at least touched upon the immense social potential of the new method of reasoning through figures. The moral fervour, so characteristic of the fully elaborated concept of sanitary statistics, could only come in to being when the interpretation of the death rate became intermingled with the concern for the moral consequences of ill health and high mortality. This, however, was realized only in the early nineteenth century.

The rational impact of numerical reasoning made itself felt also on Graunt's well-known contemporary Sir William Petty. In 1671 Petty advocated the use of the differential local death rates for the construction of a "Scale of Salubrity", to be used by an enlightened government to measure the state of health in various parts of the country. This made him call for a general statistical bureau for the collection of such material. Starting from Mercantilist assumptions, Petty thought that such an institution would enable the government to measure their power by numbering the people and, consequently, to increase the nation's strength by reducing the health hazards in those regions which showed the worst returns. Wanting to be cautious in an era of ideological crisis, he was determined to "express my self in Terms of Number, Weight, or Measure; [. . .] and to consider only such Causes, as have visible Foundations in Nature; leaving those that depend upon the mutable Minds, Opinions, Appetites, and Passions of particular Men, to the Consideration of others". ${ }^{9}$ This Baconian understanding of the truly empirical character of statistics, excluding the irritations caused by "opinions", became a favourite argument of the sanitary reformers when they tried to show that their opponents were deceived by opinions, while they themselves merely advanced facts and figures. The positivist fallacy and its appeal to people wanting to get things done added much to the impact the statistical argument had on social thought, especially when it was again employed in a period rife with opinions. Petty's other main contribution to the future definition of

8 The term "social statistics", as understood in the nineteenth century, covered both moral and vital statistics. Moral statistics were concerned mainly with matters of education, crime and intemperance. Vital statistics were the collection of data on births and mortality and their causes. "Sanitary Statistics" is a term much used in the earlier part of the nineteenth century, denoting the correlation of death rates with the hygienic conditions in which people lived. It is synonymous with vital statistics as far as the material employed is concerned, although its very name stresses the practical application of its findings.

9 W. Petty, "Political Arithmetick" (1690), in The Economic Writings of Sir William Petty, op. cit., I, p. 244. 
sanitary statistics was his notion of the "value of men", ${ }^{10}$ which introduced economic considerations into issues of health and disease which, in turn, were becoming public affairs.

In the eighteenth century, however, much of the intellectual vigour of the founding fathers was lost. Only the Prussian parson Johann P. Süssmilch ${ }^{11}$ was able to contribute markedly to the new science. Following Petty's Mercantilist argument, he became the founder of demography as the science of the wealth of nations expressible in terms of population. It was he who understood that only by taking large numbers of cases was it possible to obtain mathematically correct regularities. But Süssmilch lacked the grand perspective of his predecessors as well as their thorough rationalism. The descriptive statistics of the German type flourished, openly rejecting the numerical method. ${ }^{12}$ The plague had somehow miraculously disappeared and health problems had become less pressing. There is only one exception which significantly has to do with contagious disease, in this case smallpox. To prove the success of their various techniques of inoculation, physicians employed statistics in an "experimental" way. ${ }^{13}$ The most renowned was Edward Jenner, the crucial figure in the breakthrough of vaccination against smallpox, to whom numerical reasoning was the "eye" of a medical researcher, his essential means of observation and verification. Yet neither he nor his colleagues could escape the reproach commonly levelled against all this medicine for the mean man. To someone who had to decide about being vaccinated, the allimportant question was whether as an individual he was effectively protected by this procedure or not. Statistics merely told him how probable this might be; it could not offer any security. This "aleatory" element ${ }^{14}$ of statistics became a distinctive feature of hospital statistics. ${ }^{15}$ Sanitary

${ }^{10}$ Ibid., p. 267 , passim.

11 J. P. Süssmilch, Die göttliche Ordnung in den Veränderungen des menschlichen Geschlechts, aus der Geburt, dem Tode und der Fortpflanzung derselben erwiesen (Berlin, 1741). Cf. Westergaard, Contributions, op. cit., pp. 71-76.

12 Westergaard, Contributions, pp. 4-15.

13 Creighton, A History of Epidemics, op. cit., II, pp. 483ff.; R. H. Shryock, "The History of Quantification in Medicine", in: Isis, LII (1961), pp. 224-25; G. Rosen, "Problems in the Application of Statistical Analysis to Questions of Health, 1700-1800", in: Bulletin of the History of Medicine, XXIX (1955), pp. 27-45.

${ }^{14}$ I. Hacking, The Emergence of Probability, 2nd ed. (Cambridge, 1978), pp. 12, 123.

15 Hospital statistics were in vogue among medical men at the turn of the century (1780-1850). Since they relied only on small samples of patients, their results were not very trustworthy. In the hospitals as in epidemiology, statistics served as a link between the traditional, Galenic type of medical reasoning and the modern, scientific and experimental approach to disease. This is true, in particular, of hygiene, which formed the basis of sanitary statistics. Cf. W. Coleman, "Health and Hygiene in the Encyclopédie: A 
statistics, on the other hand, managed to circumvent this predicament by concentrating exclusively on public health and by promising not a cure, but just environmental policing of infectious disease.

Nothing demonstrates the social dimension of disease as clearly as epidemics do. Man's health depends to a large extent on the manner in which his societal environment is organized. Moreover, disease seems to him not simply an event involving physical pain, but also poses a serious challenge to his social position. The process of civilization gradually supplants the natural environment by a cultural one, and this gives rise to a set of conditions potentially favourable to the breeding and spread of contagious disease. Here, urbanization plays a crucial role because it gives new social meaning to poverty and produces specific hazards to health. The protection of health in general becomes a public affair, combining the struggle against infectious disease with the endeavour to economize a community's labour resources. Therefore, it is no accident that the discovery of the close interrelationship between the problems of health or disease and social conditions first took place in the Mercantilist era. ${ }^{16}$ Consequently, the emergence of an industrial and urban society in the earlier decades of the nineteenth century led to a social definition of medicine as a kind of public-health science. Being thus concerned with the health of the public (Quetelet's "mean man"), it aimed at prevention, avoiding the appeal to individual responsibility. Vital statistics became sanitary statistics, i.e. an attempt to combine statistical inquiry with the concern for reform in the public-health sector. Stressing that many cases of sickness and death could be avoided by means of sanitary amelioration, they proved to both the middle and working classes that social improvement was a reformist and not a revolutionary policy.

Rudolf Virchow, the great German pathologist and one of the fathers of social medicine, once spoke of epidemics as the "great warning signs" in the proces of civilization, which point to serious deficiencies in the

Medical Doctrine for the Bourgeoisie", in: Journal of the History of Medicine and Allied Sciences, XXIX (1974), pp. 399-421. With the rise of experimental physiology, hospital statistics suffered a setback, even more severe than that which befell sanitary statistics after the emergence of bacteriology.

${ }_{16}$ G. Rosen, "Die Entwicklung der sozialen Medizin", in: Seminar: Medizin, Gesellschaft, Geschichte, ed. by H. U. Deppe and M. Regus (Frankfurt/M., 1975), pp. 78-90. 
organization of society. ${ }^{17}$ Consequently, Virchow characterized this type of infectious disease as "artificial", ${ }^{18}$ and he concluded that its prevention was the responsibility of the State. Again, statistics were seen as an instrument measuring the mortality of the different social classes. This idea, namely to define death and sickness in terms of class, was the root of the ideological dynamics of sanitary statistics. Placed in this context, Petty's concept of the different degrees of salubrity shifted its focus from Mercantilism to a notion of social justice. This political interpretation of sanitary statistics was pioneered by Louis $\mathbf{R}$. Villermé, ${ }^{19}$ who influenced the public-health movements both in Britain and in Germany. In contrast to Virchow and his friends Villermé stressed the economic more than the political aspects of public health. Hygienic investigation added a sociological dimension to political economy. While in England this combination produced publichealth policy, in France such reformist consequences were delayed by a more dogmatic understanding of liberal economics. In England, the differential mortality of rich and poor people served as a kind of social health thermometer, while the interpretation of disease within the context of political economy paved the way for early notions of human capital and social costs.

The background to this development was the transformation brought about in the structure of society by industrialization and urbanization, in which Britain played a leading role. Both the extent and the rapidity of the growth of towns produced problems of a magnitude and novelty that could only be overcome by a new understanding of urban existence. At the beginning of the nineteenth century roughly 20 per cent of England's population lived in towns (i.e. settlements with 5,000 inhabitants or more). By 185154 per cent did so. In 1801 there was only one city with over 100,000 inhabitants (London), but fifty years later there were ten. By then, for the first time, the nation had more town than country dwellers. These facts are well-known. ${ }^{20}$ The rural surplus population flocked into rapidly growing cities, where they lived crowded together in huge slums. There existed hardly any.rationale in urban growth except the haphazard logic of jerry-building serving new and quickly-expanding labour markets. The absolute as well as the relative numbers for mortality, crime, suicide,

17 R. Virchow, "Die öffentliche Gesundheitspflege” (1848), ibid., p. 173.

18 Id., "Die Seuche" (1848), ibid., p. 202. He specifically singled out typhus, cholera, scurvy, tuberculosis and sweating sickness.

19 W. Coleman, Death is a Social Disease. Public Health and Political Economy in Early Industrial France (Madison, 1982), pp. 4-21, 149-61.

$20 \mathrm{Cf}$. Ph. Deane and B. R. Mitchell, Abstract of British Historical Statistics (Cambridge, 1962), pp. 94-95. 
prostitution, bastardy and poor relief, the classical data of social statistics, made a big jump. In short, the phenomenon of the "large numbers" became a dominant factor in social life. The relative balance of births and deaths, which was characteristic of an agricultural society, had quite dramatically changed. Famine and epidemics, the old check on population growth, were absent from the country during the latter part of the eighteen th century. ${ }^{21}$

This new situation gave rise to both hope and fear: hope for a new millennium ahead and fear of being drowned by a rising flood of poor people. William Godwin and Thomas Malthus became the spokesmen of the two public responses to this epoch-making social transformation. For a time the Malthusian response carried the day, ${ }^{22}$ because it was capable of formulating an answer in economic terms and expressed the apprehensions the higher classes felt when being confronted with the social implications of the French Revolution. Malthus merely echoed the conventional conviction that the poor could only be held in obedience and industry as long as their survival depended on the need to toil for a day-to-day subsistence. Moreover, the poor were only useful economically when their labour produced more than they consumed. Thus the poor, even if only partly relieved of the yoke of permanent toil, immediately became the "dangerous" classes and a strain on national prosperity. Because of their unchecked breeding, Malthus concluded, there were more mouths to be filled than hands one could usefully employ. The poor, far from being a source of a nation's wealth as the Mercantilist statisticians had claimed, were eating it up by way of poor relief. As long as the poor possessed some legal claim to subsistence, no property and no social order could be called secure. Consequently, the older nexus of law and subsistence had to be replaced by a nexus created through temporary contracts in the labour market. The poor man no longer had his "place" in society; he had to earn it again and again by exchanging labour for subsistence.

The statistical relevance of the Malthusian concept derives mainly from the quantitative structure of the argument, despite the well-known weakness of the actual data on which it was based. Godwin still put forward a speculative idea. Reality followed reason, since reason is the true reality from which all phenomena are derived. The "signs" did not possess an

21 The only exception was smallpox, which, however, never became a great killer compared with the plague or cholera, cf. Cartwright, A Social History of Medicine, op. cit., ch. 5.

${ }^{22}$ Cf. J. R. Poynter, Society and Pauperism. English Ideas on Poor Relief, 1795-1834 (London, 1969), esp.pp. 155-61. 
independent epistemological value. Therefore, the "terms of number" could not simply be added up to form a true picture of reality, they only distorted it. Against this faded reminiscence of episteme ${ }^{23}$ Malthus set his belief in techne, in statistical knowledge, which might provide "a clearer insight into the internal structure of human society". ${ }^{24}$ The human being shaped by such reasoning was a quantitative unit, and the logic of its behaviour could be well grasped by quantitative investigation. Jeremy Bentham, ${ }^{25}$ in particular, elaborated the consequences of such an anthropology. His "pain-pleasure calculus" called "man" and his hope of feeding this animated mechanism into Babbage's computer provide a striking example of a perspective which observed and measured human behaviour instead of prescribing it according to a pattern of deference. To Bentham no break was necessary to switch from his deductive theory to induction by way of facts and figures. The deductive theory was already a kind of abstract quantification, though still without numbers.

Obviously a profound transformation of social thought was under way, ${ }^{26}$ which expressed itself largely through the emergence of the statistical argument. When, for example, the "science of morals" could be conducted "like experimental physics", as Helvétius declared, then there was every reason to turn from deduction to induction in moral questions as well. Experimentation presupposed the possibility of manipulating behaviour and character by changing the conditions of social life. It depended on careful observation of mass phenomena and, therefore, on statistics. The statistical argument, however, drew its strength from the revelation of regularities and the quasi-Newtonian assumption that behind all probabilities there existed some great deterministic laws. Out of this consideration sprang the Laplacian demon, out of it grew a kind of Benthamite demon, the ruler of the Panopticon. ${ }^{27}$ It is the deterministic "if" behind utilitarian statistics. This idea inspired environmentalist enthusiasm, and was responsible for the intimate relationship between statistics and social

23 This intellectual attitude was also held by the Romanticists and was made the method of social criticism by Carlyle and Ruskin. See, for example, Thomas Carlyle's rejection of statistics as a means of social understanding in his essay on Chartism (1839), in English and Other Essays (London, 1967), pp. 170-74, passim.

${ }^{24}$ Th. Malthus, An Essay on the Principle of Population, 6th ed. (London, 1826), I, pp. 19-20.

${ }^{25}$ Of the vast literature on Bentham and Benthamism, the best survey is still E. Halevy, The Growth of Philosophic Radicalism (London, 1928, reprinted 1972).

${ }^{26}$ For a thoroughly critical, penetrating analysis see E. Voegelin, From Enlightenment to Revolution (Durham, North Carolina, 1975).

${ }^{27}$ Cf. J. Bentham, Traités de Législation Civile et Pénale (Paris, 1802), p. 209; Voegelin, From Enlightenment to Revolution, p. 60. 
reform in the years to come. The fiction of the demon represented the belief that men could be conditioned correctly, i.e. that social conditions were subject to reasoned alterations. But this demon did not stand for the invisible hand or for statistical regularities. Crime, poverty and, above all, epidemic disease produced figures and even correlations that contradicted a position of coherent laissez-faire. So the demon was called forth to ensure the desired regularities and to eliminate the undesired ones. This duality of invisible hand and Benthamite demon is characteristic of the utilitarian interpretation of liberalism, from which sanitary statistics followed.

The homo benthamiticus was the mean man as the ideal man, a truly democratic creature of the large number, with the homo panopticus as the tail of the normal curve. Society was an aggregate of such mean men pursuing mean happiness. This was obviously a quantitative conception, although it was still quantification without numbers. An effective quantitative approach, then, could attempt to measure happiness in terms of consumption per head of certain goods. But it might also measure it through average life expectancy in years. The first measurement became only possible, it seems, when consumer goods began to dominate industrial production and when mass consumption was already well above the subsistence level. This development did not take place at least until the end of the nineteenth century. But the happiness connected with health and long life could be measured even in the early decades of the century. That it had to be measured was commonplace in a philosophy that had as its basis nothing but man's physical nature. When the Malthusian fear of a human deluge gave way to the industrial concept of manpower, the protection of such manpower became a concern worth the trouble. The health of the nation gradually evolved as an essential part of policy-making in industrial societies. And here, again, quantification as a numerical thermometer was called upon to guide and propagate reform.

Of course there had already been attempts of a similar kind, notably the work of the Manchester physician Thomas Percival in the late 1780 's. ${ }^{28}$ But one had to wait for the ravages of epidemic disease in order to be able to combine the plea for sanitation and ventilation with the case for statistics, thereby creating the new policy and science of public health. It was through this novel science that the world's first industrial society responded for the first time to the environmental changes it had brought about. And it was

28 Th. Percival, "Observations on the State of Population in Manchester" (1789), reprinted in Population and Disease in Early Industrial England, ed. by B. Benjamin (Farnborough, 1973). Percival was a pioneer both in the foundation of the Manchester Board of Health as an emergency institution and in the promotion of the first campaign for factory legislation. 
this response which heralded "the hygienic rebirth of the nations". ${ }^{29}$ The rise and decline of the poor rates functioned as a first, though indirect, statistical index. Epidemic disease pushed the rates up and stimulated enough economic interest among poor-law officials and the rate-paying classes to justify some investigation into its causes and possible remedies. The fear of contamination and the mounting criticism of quarantine ${ }^{30}$ furthered the notion of a preventive, statistically controlled public-health policy. This implied a considerable meddling with society, which was offensive to both traditionalists defending the autonomy of local selfgovernment and liberals professing the effectivity of the invisible hand of the market. It was an unpleasant surprise for them to realize that at least in the field of public health such a helpful hand was nowhere to be found. True, there were enough regularities, but they revealed disorder in the form of poverty and disease. Therefore, the sanitary statisticians concluded, it was the task of public-health policy to provide something like a political calculation of errors within the broader context of liberal politics. The "arm of flesh" had to help out when the invisible hand was proved wrong through statistical reasoning.

During the following decades, the late 1830's and the 1840's, statistics as the scientific basis of public health experienced its "era of enthusiasm". ${ }^{31}$ Cholera and Chartism were added up to the "Condition of England" question, which deeply influenced the social thought of the time. Statistical information, one of the numerous statistical societies pronounced to its members, "gives aim and effect to the energies of the philanthropist; it furnishes the legislator with materials on which to form remedial measures for social happiness. [. . .] From information thus furnished [. . . the public attention has been fastended [...] upon the physical and moral degradation of the poorer classes in the metropolis and many of our large towns." 32 Statistical reasoning seemed to promise the possibility that an objective concept of reality might be developed by reducing complex phenomena to "terms of number", which Petty had hoped for a century and a half earlier. Quite a few contemporaries thought that statistics would stimulate a consensus within a much divided public and that it might even lead to a veritable "science of government", which might overcome the

29 Th. Weyl, "Überblick über die historische Entwicklung der Städtereinigung bis zur Mitte des neunzehnten Jahrhunderts", in: Handbuch der Hygiene, ed. by Th. Weyl, 2nd ed. (Leipzig, 1912-22), II, p. 22.

${ }^{30}$ E. Ackerknecht, "Anticontagionism between 1821 and 1867", in: Bulletin of the History of Medicine, XXII (1948), pp. 567, 589, 592-93.

31 Westergaard, Contributions, ch. 13.

32 From a declaration of the Royal Cornwall Polytechnic Society (1840), quoted ibid. pp. 141-42. 
prevailing party spirit of the age. ${ }^{33}$ The 1830's and 1840's, it should be remembered, were the formative period of political parties. It was a period which commenced with the bitter struggle over the Reform Bill of 1832, and ended with the no less hotly debated issue of the Corn Laws in the late 'forties. In the quest for a consensus in such troubled times, there was a temptation to switch in one's argumentation from "opinions" to "facts and figures".

In this development cholera functioned as a catalyst. When it broke out in Britain in October 1831, the government, following medical advice, imposed a quarantine, and called for diseased persons to be kept in special isolation hospitals, ${ }^{34}$ which were, together with those administering vaccination against smallpox, among the first institutions providing State medicine for citizens, not just for paupers. These measures followed the pattern of plague prevention of the sixteenth and seventeenth centuries, but were ill adapted to the emerging industrial society of the day, dependent as it was on regular imports and exports of raw materials and goods. Consequently, they aroused bitter opposition, and with the cessation of the epidemic ${ }^{35}$ medical policing was allowed to lapse. Yet cholera had revealed much about the social condition of the people. It had demonstrated the need for a long-term preventive policy, and unveiled the precarious relationship between poverty and disease. ${ }^{36}$ Both aspects had considerable political consequences. The central Board of Health, set up temporarily for the struggle against cholera, and many of the local boards were eager to collect figures showing whether the epidemic was spreading or declining. Because of the ignorance as to the causes of the epidemic and the helplessness of the physicians even in providing a correct diagnosis, these figures offered the only means to get some information about this terrible disease. ${ }^{37}$ They also showed that cholera was primarily a "poor man's disease" which, however, could invade a rich man's house. In this context, the miasmatic explanation of disease fit exceedingly well into the socio-political situation of the day. It reflected the growing uneasiness

${ }_{33}$ M. J. Cullen, The Statistical Movement in Early Victorian Britain (Hassocks, 1974), pp. 12, 20,82, 85, 146.

${ }_{34}$ There are quite a few publications on the first cholera epidemic of 1832: N. Longmate, King Cholera. The Biography of a Disease (London, 1966); R. J. Morris, Cholera 1832. The Social Response to an Epidemic (London, 1976); M. Durey, The Return of the Plague. British Society and the Cholera of 1831-32 (Dublin, 1979); Creighton, History on Epidemics, op. cit., II, pp. 796-835.

${ }_{35}$ Cholera killed some 31,500 people during its first outbreak in Britain, cf. Morris, Cholera 1832, p. 13.

36 Morris, Cholera 1832, pp. 35, 84-117; Durey, The Return of the Plague, op. cit., pp. 185-200.

37 Morris, Cholera 1832, pp. 81-83, 159-92. 
about quarantine, and allowed for the extensive use of statistics, taking the problem out of the hands of the medical profession and transferring it into those of the sanitary reformers. Medical research into epidemic disease studied numerous case-histories, and to sum them up and look for correlations seemed to be the only method promising success. Moreover, because epidemics such as cholera and typhus were environmental diseases, the living conditions of the urban poor for the first time became an object of public concern. Consequently, the foundation was laid for the marriage of statistics and social reform.

The search for useful knowledge has always been the social impetus for statistics. And it was sanitary statistics with its focus on utility that kept this impetus alive. In 1837 typhus was spreading in the poorer quarters of London, resulting in a marked increase in poor-relief expenditure. The central poor-law authority, the Poor Law Commission, wanted to keep the rates down, and ordered three physicians to inquire into the causes of the epidemic and explore remedies. The doctors' suggestions were accepted with approval. They stated that epidemics were caused by miasmata, i.e. "certain poisons disseminated in the air [...]. Of these the most noted are the matters of small-pox, measles, hooping-cough, and that called malaria, [...] which is generated wherever animal and vegetable substances are undergoing putrefactive decomposition, and which produces a great variety of fevers." In order to prevent future epidemics one had, therefore, to remove "completely the noxious animal and vegetable matters brought to or produced in cities". ${ }^{38}$ Sanitation was proclaimed social salvation. And sanitation meant removal of waste, construction of sewers, better ventilation through wider streets and more windows, regular water supply and the sweeping of streets. This would ban the miasma from British towns, the sanitarians promised. For the miasma obviously was an enemy of free individual agency, attacking a free man's property, his life and ability to labour, like a highwayman. To protect society against it seemed to be but a principle of fairness rightly to be claimed by each of its members.

III

Since every epidemic is a mass phenomenon, it seems promising to analyse it in terms of figures. Urbanization and mobility favour the spread of epidemic disease. And it should not be forgotten that until the development of bacteriology in the 1870 's medical men held various, often con-

38 Fourth Annual Report of the Poor Law Commissioners (London, 1838), pp. 103, 105. The quotations are taken from the report of two of the physicians, Neil Arnott and James Ph. Kay. 
flicting, ideas about the causes of an epidemic. Using the numerical device when observing a phenomenon that was characterized by large numbers made sense to people who were eager to argue "scientifically" only. Because the notion of "ultimate causes" remained unclear within the very general concept of miasma, sanitary statisticians felt no need to be concerned with the difficult search for hidden causes. They could turn at once to the study of the numerical correlations between different hygienic levels and the respective occurrences of "fevers" ${ }^{39}$ In such a manner statistics could become something like a numerical microscope of the new science of public health. It also changed the meaning of hygiene from a kind of medical self-help pursued by individuals to a largely public affair involving State-controlled sewerage and water supply. Hygiene was transformed from a "medical doctrine for the bourgeoisie" (William Coleman) into a medical policy for the working classes.

"The spirit of the present age has an evident tendency to confront the figures of speech with the figures of arithmetic", the Statistical Society of London asserted in $1838 .^{40}$ Quantitative social medicine, i.e. public-health science, played an influential role in this confrontation. Its four most remarkable representatives were the overpowering poor-law official Edwin Chadwick, ${ }^{41}$ and the three physicians William Farr, ${ }^{42}$ Thomas Southwood Smith $^{43}$ and John Snow. ${ }^{44}$ In his sensational Report on the Sanitary Condition of the Labouring Population of Great Britain, published in 1842, Chadwick was determined to demonstrate statistical correlations between the sanitary conditions of the different social classes and their corresponding average life expectancy. ${ }^{45}$ To Chadwick, as to his collaborators in sanitary affairs, the essential business was "to minimise the volume of pain and to maximise the volume of pleasure". ${ }^{46}$ It was only consistent to

39 E. Chadwick, Report on the Sanitary Condition of the Labouring Population of G. Britain, 1842, ed. by M. W. Flinn (Edinburgh, 1965), pp. 80-99, 220-27, 246-54, 422-23.

40 Quoted by V. L. Hilts, "Statist and Statistician. Three Studies in the History of Nineteenth Century British Statistical Thought" (Ph.D., Harvard University, 1967), p. 135.

41 R. A. Lewis, Edwin Chadwick and the Public Health Movement (London, 1952).

42 J. M. Eyler, Victorian Social Medicine. The Ideas and Methods of William Farr (Baltimore, London, 1979).

43 C. A. Lewes, Dr. Southwood Smith. A Retrospective (London, 1898).

44 M. Pelling, Cholera, Fever and English Medicine, 1825-65 (Oxford, 1978), ch. 6.

${ }_{45}$ Chadwick, Report on the Sanitary Condition, op. cit., pp. 76-77, 220-66. On the public reception of the Report see Lewis, Chadwick and the Public Health Movement, op. cit., pp. 60-65; Pelling, Cholera, Fever and English Medicine, pp. 39-45. On similar developments in France cf. Coleman, Death is a Social Disease, op. cit., chs 6 and 8.

46 Lewis, Chadwick and the Public Health Movement, p. 27. 
attempt to translate these volumes of pain and pleasure into "terms of number", and then to measure the varying degrees of salubrity of different trades, different social classes or different parts of the country. The statistical health thermometer revealed a great discrepancy between town and country and between the social classes. The average life expectancy, for example, was 52, 41 and 38 years for gentry and professional classes, farmers and tradespeople, and artisans and labourers, respectively, in rural Rutlandshire, and 38, 20 and 17 years in Manchester. These were dramatic figures, though it was argued that calculating life expectancy at birth produced a somewhat distorted picture. ${ }^{47}$ Although some critics objected to Chadwick's crude statistical techniques, ${ }^{48}$ they shared his conviction that it could be shown "how subordinate are the subjects of common declamation as 'condition of the people questions' to that of their sanitary condition". ${ }^{49}$

Regarding statistical sophistication, William Farr was the outstanding figure among the sanitary reformers. Farr, from 1839 the leading official of the newly founded General Registrar's office, wanted to ensure the scientific character of public health by proving that the "death-force" was law-abiding and that its regularities could be revealed by statistical investigation..$^{50}$ Therefore he attempted to formulate the reformist conception of the "Sanitary Idea" as a mathematically shaped law, according to which mortality increased in proportion to population density provided that there was no change in the prevailing sanitary conditions. ${ }^{51} \mathrm{He}$ deduced his law from several series of statistical correlations. Fluctuations in mortality by constant ratios of density were explained by differences in the corresponding sanitary environment. Farr never gave up his hope of contributing to a public-health science proceeding in an astronomical manner. "Generations of men, like the heavenly bodies, have prescribed orbits, which analysis can trace." 52 The great model of a statistical law was T. R. Edmonds's "law of mortality", which demonstrated that mortality was

47 E. Chadwick, The Health of Nations. A Review of the Works of Sir Edwin Chadwick, ed. by B. W. Richardson (London, 1887), I, pp. 33-38, 77-78.

48 Moreover, Chadwick compared only mean ages at the time of death, thus neglecting the different age composition of the social groups involved. Cf. Cullen, The Statistical Movement, op. cit., pp. 58-61.

49 Chadwick, "On the best Modes of representing accurately, by Statistical Returns, the Duration of Life, and the Pressure and Progress of the Causes of Mortality amongst the Different Classes of the Community", in: Journal of the Statistical Society of London, VII (1844), pp. 24-25.

50 Eyler, Victorian Social Medicine, op. cit., p. 69.

51 Ibid., pp. 132, 145-47. This idea was put forward by Farr for the first time in 1839.

52 Ibid., p. 32. 
geometrically related to age. Such a law made it possible to predict mean events and to correct life tables based simply on the experience of "empirics". Behind this "astronomical" reasoning lay the conviction that the socio-biological sphere was also law-abiding. Farr tried to find a mathematical formula for the miasmatic explanation of cholera by inversely relating the cholera mortality of the different metropolitan districts to their mean elevation above the Thames. ${ }^{53}$ Once assured of its scientific character, public health could apply its authority to politics, serving as a socio-biological "thermometer" or "biometer" (Farr). ${ }^{54}$ A mortality of 17 deaths per 1,000 inhabitants was proclaimed as a threshold mark. Every single death above this value was to be measured as one degree of insalubrity which made it possible to quantify at least one crucial aspect of the well-being and happiness of the average man. Finally the cherished idea of a Petty or a Bentham came within the reach of the administrators, who even began to employ a calculating machine of the Babbage-type to master the rising flood of numbers.

All this had considerable consequences for political decision-making. Local self-government seemed to be threatened and many respectable citizens, being both rate-payers and landlords, feared that sanitary improvements would put the main financial burden upon their class. The working classes, for whom most of sanitation was done, remained passive or chanted Chartist slogans. In this situation the sanitary reformers felt even more obliged to expound their message that sanitation meant social salvation because of the intimate relationship between sanitary and moral statistics: filth bred moral filth, disease bred moral disease. Give the labouring poor in our cities abundant clear water and decent privies and, if possible, reduce overcrowding, and the main sources of working-class unrest will be dried up. The "Condition of England" question was, then, primarily a sanitary-conditions-in-England question. In this way publichealth policy was an integrative social policy. Its double purpose was to remove the "moral pestilence" threatening the labouring classes together with typhus and cholera. ${ }^{55}$ This contrast between "clean and provident" and "dirty and pauperized" formed one part of the ideological background against which the enthusiasm stimulated by sanitary statistics must be seen. The other part was the hope that statistics might foster consensus in a

\footnotetext{
53 Ibid., p. 114-21.

54 Ibid., pp. 68-69.

55 Cf. A. Briggs, "Cholera and Society in the Nineteenth Century", in: Past \& Present, No 19 (1961), pp. 76-96; Hilts, "Statist and Statistician", op. cit., pp. 178-98; Cullen, The Statistical Movement, op. cit., pp. 65-74.
} 
society stricken with political conflict. The result of the reformist optimism thus created was a measurable improvement in the health of towns. Life expectancy at birth increased from 40.2 years in 1841 to 51.5 in 1911. The ratio of urban to rural deaths, which had been crucial to public-health policy, declined from $124: 100(1851-61)$ to $114: 100$ (1891-1901). ${ }^{56}$

Hardly less important was the emerging idea of the protection of health as a political issue. Statistics, functioning as a health thermometer, did much to draw public attention to faulty sanitary conditions, thereby putting pressure on many a reluctant local authority. The great Public Health Act of 1848 officially accepted this use of mortality statistics as a means of measuring public health. It set an annual death rate of $23: 1,000$ as a threshold mark. If this rate was surpassed, the newly established central Board of Health could enforce sanitary measures by the local authorities. ${ }^{57}$ The act reflected the duty of the State to protect the health of its citizens, and this was an important step toward the formation of an interventionist social policy. Another, more provocative statistical standard was the socalled "healthy district" mortality rate of $17: 1,000$. Farr had found that in 1850 one tenth of the reporting districts had an annual mortality of $17: 1,000$ or less. To him this rate represented the inevitable physiological mortality, which led him to the calculation of the "degrees of insalubrity". ${ }^{58}$ In comparing the "healthy district" mortality rate with the actual death rate, it became possible to quantify the negligence of sanitary authorities and turn it into a political issue. Because infant mortality was high ${ }^{59}$ the sanitary reformers also used infant-mortality rates as an index of domestic hygiene and public sanitation. Other interesting applications of statistics to problems of public health were the fields of occupational diseases, motivated mainly by factory legislation, and epidemiology, upon which the scientific claims concerning public health were primarily based.

Public health and sanitary statistics first became a political issue in the early 1840's, when the sanitary movement was formed by a group of bureaucrats like Chadwick and Farr, philanthropists like Lord Shaftesbury, and a handful of politicians and doctors. ${ }^{60}$ Sanitary reform, made

56 A. S. Wohl, Endangered Lives. Public Health Policy in Victorian Britain (London, 1983), p. 329.

${ }^{57}$ S. E. Finer, The Life and Times of Sir Edwin Chadwick (London, 1952), pp. 325-26; Eyler, Victorian Social Medicine, p. 137. The average for England and Wales was $21: 1000$.

58 Eyler, Victorian Social Medicine, pp. 71-72, 132-42.

59 In the decade 1851-60 the mortality of children under the age of five made up nearly 80 per cent of the difference between the most and the least healthy districts.

60 See R. G. Patterson, "The Health of Towns Association in Great Britain, 1844-49", in: Bulletin of the History of Medicine, XXII, pp. 373-402. 
respectable through statistical investigation, seemed to offer a royal road to moderate reform, avoiding both "Turkish indolence" and Chartist upheaval. But neither government nor Parliament were inclined to interfere with such powerful interests as private property or local self-government, and so the reformers had to win public opinion for their cause. Here the application of the statistical thermometer and the disturbing calculation of degrees of insalubrity proved to be a persuasive argument in the attempt to introduce the problem of health into the public discourse of the time. ${ }^{61}$ The ensuing "war of the clean and the dirty parties", as Lord Palmerston was later to call the struggle between the advocates and the opponents of sanitary reform, was the first public debate in which statistics played a major role. This debate took statistics out of the hands of the insurance business and made it a tool of social reform. The old meaning of statistics, namely to study the "arts of civil life" in order to encourage enlightened government, was joined together with its new meaning, i.e. the stress on the numerical method and the democratic appeal to public opinion. In this manner, sanitary statistics served the need for social orientation in a period of ideological confusion. It also provided a standpoint from which the middle classes could view the people below them without apprehension. The great act of 1848 ended the period of agitation, and with it the era of statistical enthusiasm died away. The hungry 'forties were over, the prosperous mid-Victorian years began. The steady improvement of hygienic standards of urban life in the years to follow and a marked rise of the overall standard of living lessened the attraction of reformist rhetoric and sanitary statistics. The emergence of a labour aristocracy, which was to dominate working-class politics in the following decades, added to this tendency. The statisticians lost their hold on the public mind.

The discussion of the condition-of-the-people question in the 1830's had created a public susceptible to the statistical presentation of social problems. This promise of an objective analysis of fearful social phenomena and its epochal corollary, gradual reform, was transformed into a political programme in the 'forties, when the statistical method was firmly applied to problems of public health. The indifference, sometimes even hostility, to a notion of social improvement focussing on poverty and a more flexible administration of poor relief stood in marked contrast to the overwhelming importance attached to the improvement of public health. ${ }^{62}$ Sanitation

${ }^{61}$ Cf. W. C. Lubenow, The Politics of Government Growth, 1833-47 (Newton Abbot, 1971), pp. 69-146.

62 This attitude was typical of the reformers who supported the New Poor Law of 1834 as a bulwark against the "impudence" of the undeserving and work-shy class of paupers, as 
made sense within the radical philosophy of pauperism and self-help, but a generous distribution of poor relief did not. Sanitation met the challenge of urbanization. So the statistics of death replaced the rudimentary statistics of poverty when reformism took hold of the numerical method. The miasma theoreticians had been convinced that they could prove a causal relation between miasmatic factors (such as foul air, high humidity, the accumulation of waste, and the effluvia of sewers and cesspools) and their corresponding diseases (in particular cholera, typhus, typhoid and tuberculosis). It was bad luck for them, though good luck for those whose health they were charged to protect, that in 1849 a physician, John Snow, could demonstrate statistically that cholera was caused by polluted drinking water ${ }^{63}$ At about the same time William Budd of Bristol put forward his fungus theory based upon microscopical research. Farr and John Simon, the first Medical Officer of Health in London and later an influential health official, were now obliged to conduct an independent inquiry, although they still believed in the miasma doctrine. Analysing the statistical data for the cholera years $1848-49$ and 1853-54, they had to acknowledge that Snow's thesis must be correct (1856). The final breakthrough came in 1866, when Farr could statistically trace the source of an explosive epidemic to the contaminated wells of a certain water company.

Farr's report was a new triumph of sanitary statistics. But appearances were deceptive. Statistical research could not answer the question regarding the ultimate causes, that of the mysterious materies morbi. Statistical epidemiology had to be linked with bacteriology, and the microscope began to replace figures as primary instrument of observation. The same holds true of clinical statistics. ${ }^{64}$ The numerical method as a diagnostic means in addition to the physicians' experience may have provided a link between the traditional practice of relying on medical "tact" and the modern concept of scientific medicine built upon the microscope and chemistry. From the 1870's on bacteriology revolutionized medicine.

the lowest stratum of the labouring poor were called by the higher classes. Suggestions advanced by the leading Scottish health-reformer, the Edinburgh professor of medicine, William Alison, to relate public health to problems of poverty, fell on stony ground in England. Cf. Alison's remarkable contribution to the Local Reports on the Sanitary Condition of the Labouring Population of Scotland (London, 1842), pp. 13-22.

${ }^{63}$ Cartwright, A Social History of Medicine, op. cit., pp. 107-10. Snow proved his thesis by comparing epidemic mortality in several metropolitan districts served by different water companies. The ratio varied from 315 deaths per 1,000 inhabitants to $57: 1,000$, although there was no marked difference regarding miasmatic criteria. For an exhaustive discussion of Snow's work see Pelling, Cholera, Fever and English Medicine, ch. 6.

64 Westergaard, Contributions, pp. 150-53, 156. 
Sanitary statistics withdrew to the less spectacular field of occupational diseases and their prevention, thereby stimulating some useful factory legislation. Mathematically unsophisticated as it had been since its separation from actuarial statistics and cut off from its former source of reformist enthusiasm, sanitary statistics entered a period of stagnation in the decades of Victorian equipoise. Things began to move again only at the end of the century. While the biometric school sought to reconstruct statistics as a mathematically grounded science, the older reformist branch finally broke away and became known as empirical sociology.

IV

In conclusion we can describe the statistical movement of the 1830's and 1840 's as part of the social reaction to industrialization. Society could no longer be understood in terms of status and traditional wisdom. It changed rapidly and profoundly, and since this process was accompanied by mass phenomena, the use of figures in analysing it was only common sense. The cash nexus obviously corresponded with such a quantitative conception. Epidemics and big towns are classical instances of large numbers. Both gave rise to statistics in the seventeenth century, both nursed it in the nineteenth century. Statistics worked within a framework of deterministic thought. In the seventeenth century men turned to a depersonalized Providence; two centuries later political economy, as a rigid deductive system, presented a similar law-abiding universe, within which the statisticians were constructing their theories. This is, for example, shown by Farr's fondness of astronomical analogies and his numerous attempts to transform numerical correlations into law-like regularities. In the intellectual effort of the generation of the Industrial Revolution to produce a pattern of interpretation to fit their new social world, statistics formed one of the intellectual bridges between social thought and social reality.

The search for laws, then, provides the link between the overwhelming variety of reality and the dogmatic framework of interpretation which political economy was to the expanding industrial society throughout much of the century. A crucial element in this interrelation is the Baconian maxim "Knowledge is power". Petty related it to statistical inquiry, and the statistical enthusiasm of the nineteenth century had much to do with the potential power of knowledge. This Baconian spirit brought statistics and the "Condition of England" question together. The epidemic played the role of a catalyst in this process. In the first half of the century some kind of public-health policy became a necessity if Farr's social-density law was not to ruin the liberal prospects of urban civilization. Statistics not only offered 
the most suitable tool for an investigation of mass phenomena; it also allowed for the interpretation of its data according to the liberal preconceptions of social policy. Measuring a man-made world, statistics brought home to society the expected as well as the unforeseen results of social action and, thus, became an important factor in the transformation of such action into rational planning. In this respect it has now become one of the main agents of modern society. 